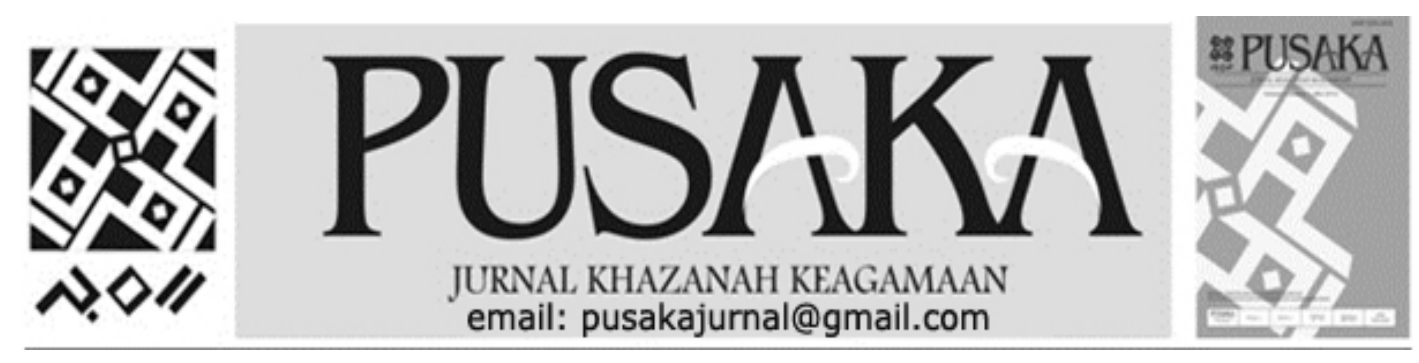

\title{
Budaya Patriarki dan Kekerasan Terhadap Perempuan (Sejarah dan Perkembangannya)
}

\author{
Patriarchal Culture and Violence Against Women \\ (History and Development)
}

\section{Israpil}

Balai Penelitian dan Pengembangan Agama Makassar

J1.A.P.Pettarani No.72 Makassar. Telp:0411-452952

Email: apillitbang@yahoo.com

\begin{tabular}{|c|c|}
\hline $\begin{array}{c}\text { Info } \\
\text { Artikel }\end{array}$ & Abstract \\
\hline $\begin{array}{c}\text { Diterima } \\
6 \\
\text { Juni } \\
2017 \\
\text { Revisi I } \\
2 \\
\text { Agustus } \\
2017\end{array}$ & $\begin{array}{l}\text { Masyarakat Indonesia secara kultural memang sangat kental dengan adat patriarki. } \\
\text { Patriarki adalah konsep yang digunakan dalam ilmu-ilmu sosial, terutama dalam } \\
\text { ilmu Antropologi. Konsep patriarki dan kekerasan terhadap perempuan menjadi } \\
\text { pembahasan utama dalam makalah ini. Budaya patriarki secara turun temurun } \\
\text { membentuk perbedaan perilaku, status dan otoritas antara laki-laki dan perempuan, } \\
\text { distribusi kekuasaan laki-laki memiliki keunggulan dibanding dengan perempuan } \\
\text { dalam satu atau lebih aspek, seperti penentuan garis keturunan (keturunan } \\
\text { patrilineal eksklusif dan membawa nama belakang), hak-hak anak sulung, otonomi } \\
\text { pribadi dalam hubungan sosial, partisipasi dalam status publik dan politik. Laki- } \\
\text { laki memonopoli seluruh peran. Hubungan yang timpang itu seringkali } \\
\text { memunculkan konflik di dalam masyarakat, terutama konflik dalam rumah tangga } \\
\text { yang berujung pada tindak kekerasan terhadap perempuan. } \\
\text { Kata Kunci: Patriarki, kekerasan, perempuan }\end{array}$ \\
\hline $\begin{array}{c}\text { Revisi II } \\
25 \\
\text { September } \\
2017\end{array}$ & $\begin{array}{l}\text { Indonesian society is culturally very thick with patriarchal customs. Patriarchy is } \\
\text { a concept used in the social sciences, especially in the science of Anthropology. } \\
\text { The concept of patriarchy and violence against women becomes the main } \\
\text { discussion in this paper. The hereditary patriarchal culture shapes the differences } \\
\text { in behavior, status and authority between men and women, the distribution of male } \\
\text { power has advantages over women in one or more aspects, such as the } \\
\text { determination of lineages (exclusive patrilineal offspring and carry last name), the } \\
\text { right son's sons, personal autonomy in social relations, participation in public and } \\
\text { political status. Men monopolize all roles. The lame relationship often creates } \\
\text { conflicts within the community, especially the domestic conflicts that lead to } \\
\text { violence against women. } \\
\text { Keywords: Patriarchy, violence, women }\end{array}$ \\
\hline
\end{tabular}




\section{PENDAHULUAN}

Konsepsi persepsi patriarki
pada prinsipnya didasari oleh pandangan paternalis yang memberikan asumsi bahwa dalam sistem sosial, keberadaan bapak atau laki-laki menjadi suatu fenomena yang menentukan terwujudnya struktur fungsionalisme dalam keluarga. Konsep paternalis merupakan signifikansi simbol bahwa laki-laki adalah simbol sistem kepemimpinan yang berdasarkan hubungan antara ibu dan anakanaknya dalam membentuk sebuah dinamika kehidupan sosial yang utuh (Goode, 2007: 18).

Penerapan persepsi patriarki dalam esensinya pada sistem sosial dan tatanan sosial menempatkan peran dari aktor-aktor sosial sangat diperhatikan. Sastryani (2007: 65) menyatakan bahwa persepsi patriarki merupakan sistem dari pengelompokan sosial yang sangat mementingkan garis turunan bapak atau dengan kata lain esensi laki-laki menjadi pertimbangan utama untuk ditempatkan sebagai obyek pelaku dari sistem sosial.

Kehidupan keseharian sering mewarnai implementasi sistem sosial yang menjadikan patriarki sebagai sebuah prasyarat di dalam menciptakan tatanan sistem sosial yang terkonstruksikan. Berry (1992: 124) menyatakan masyarakat yang menganut sistem sosial selalu menjadikan patriarki sebagai tolok ukur dalam melihat hubunganhubungan yang terjalin dalam struktur dan fungsi sosial. Semua yang melekat dalam diri individu masyarakat selalu mengedepankan nilai patriarki seperti selalu mengutamakan kondisi hukum berdasarkan garis bapak, memakai nama bapak, warisan harta bapak dan ketua adat atau bentuk-bentuk yang mendominasi eksistensi bapak.

Implementasi dari patriarki dalam sistem sosial sangat berperan penting menjadikan laki-laki atau bapak sebagai pendamping bagi perempuan. Pandangan ini yang melahirkan adanya persepsi gender bahwa laki-laki dan perempuan memiliki sifat yang berbeda, sehingga laki-laki memiliki dominasi untuk mendapatkan penghargaan, penghormatan dan menjaga kewibaannya. Perempuan harus mampu melakukan pembagian tugas yang bersifat urusan rumah tangga dan senantiasa menjaga pengungkapan kasih sayang dalam menjaga kondisi emosional dan psikis dari laki-laki untuk selalu eksis dengan kemampuan patriarkinya.

Prinsipsinya, persepsi patriarki di kalangan masyarakat yang menganut sistem sosial selalu menjadikan laki-laki sebagai hal yang berperan penting di dalam mengangkat harkat perempuan. Nilai patriarki tersebut esensi dengan kuadrat bahwa perempuan ditakdirkan untuk mendampingi lakilaki dalam menjaga eksistensi, ketokohan, penghargaan, kewibawaan, pelaksanaan tugasnya, dan pengungkapan kasih sayang dalam rangka menciptakan tatanan sosial yang lebih harmonis dan berimbang (Spradley, 2007: 34).

Berdasarkan prinsip tersebut secara Sosiologi dipandang bahwa persepsi patriarki pada prinsipnya memiliki keterkaitan dengan eksistensi gender. Mulia (2014a: 43) mengatakan bahwa perempuan dan 
laki-laki adalah setara, dalam melakukan upaya-upaya transformasi dan humanisasi, dimulai dari diri sendiri, keluarga dan masyarakat demi terwujudnya masyarakat yang berkeadaban.

Perempuan dapat menekuni aktivitasnya di ruang publik dengan baik, kerja domestik di rumah tangga, hendaknya dibagi secara sukarela bersama laki-laki. Ayah dan ibu membuat kesepakatan bersama tentang pengelolaan tugas-tugas di rumah tangga; anak-anak laki-laki dan perempuan mendapatkan tugas yang proporsional sehingga beban di rumah tangga dapat dipikul bersama. Dengan begitu, mitos segregasi kerja yang selama ini dianut di masyarakat, yaitu bahwa tugas perempuan semata-mata mengurus rumah tangga dan laki-laki hanya mencari nafkah di luar rumah, dapat dieliminasi secara bertahap. (Mulia, 2014a:47).

Keseimbangan proporsi tersebut dilihat bahwa kodrat perempuan merupakan pengabdian kepada laki-laki. Ini berarti, kaum perempuan dan laki-laki tidak dapat disamakan dalam pengembangan sifat dan karakter, yang dapat dipersamakan hanya bertalian secara struktural dan fungsional dalam sistem sosial suatu masyarakat.

Memahami secara gender, lakilaki ditakdirkan telah memiliki sifat dominan yang kuat, keras, butuh penghargaan, penghormatan dan kewibawaan, berani, lugas dan memiliki komitmen yang tinggi. Perempuan memiliki sifat dominan lemah, senang dipuji, mempersolek diri, telaten, senang dengan keindahan, suka menyayangi dan mencintai.

\section{PEMBAHASAN \\ Pengertian Patriarki}

Patriarki adalah sebuah sistem sosial yang menempatkan laki-laki sebagai sosok otoritas utama yang sentral dalam organisasi sosial. Posisi laki-laki lebih tinggi dari pada perempuan dalam segala aspek kehidupan sosial, budaya dan ekonomi. (Pinem, 2009:42).

Ayah memiliki otoritas terhadap ibu, anak-anak dan harta benda. Secara tersirat sistem ini melembagakan pemerintahan dan hak istimewa laki-laki dan menuntut subordinasi perempuan. Bahkan dinilai sebagai penyebab dari penindasan terhadap perempuan. (Walkins, 2007: 120)

Patriarki adalah konsep yang digunakan dalam ilmu-ilmu sosial, terutama dalam Antropologi dan studi referensi feministas ke distribusi kekuasaan antara laki-laki dan perempuan di mana laki-laki memiliki keunggulan dalam satu atau lebih aspek, seperti penentuan garis keturunan (keturunan patrilineal eksklusif dan membawa nama belakang), hak-hak anak sulung, otonomi pribadi dalam hubungan sosial, partisipasi dalam status publik dan politik atau agama atau atribusi dari berbagai pekerjaan laki-laki dan perempuan ditentukan oleh pembagian kerja secara seksual.

Pengertian lainnya mengemukakan patriarki adalah sistem sosial hubungan gender yang di dalamnya terdapat ketidaksetaraan gender. Laki-laki bermonopoli akan seluruh peran. (Manurun, dkk. 2002: 131). Relasi gender adalah relasi sosial antara laki-laki dengan perempuan dan melekat dalam beragam institusi sosial dan struktur 
sosial. Konsep patriarki menggabungkan konsep hubunganhubungan gender, dan kemudian berkembang menjadi dua pandangan. Pertama, meliputi ketidakadilan yang sering terjadi dalam relasi gender. Kedua, menarik perhatian kepada keterhubungan antara beberapa aspek hubungan-hubungan gender yang berbeda yang kemudian membentuk sistem sosial.

$\begin{array}{ccc}\text { Dalam } & \text { berbagai } & \begin{array}{r}\text { aspek } \\ \text { kehidupan }\end{array} \\ \text { sosial } & \text { terdapat }\end{array}$
ketidakadilan gender, di mana perempuan sering tidak diuntungkan jika dibanding dengan laki-laki. Contohnya, dalam pekerjaan, terdapat kesenjangan gender dalam upah, di mana perempuan rata-rata di bayar lebih rendah dari laki-laki. Perempuan mengerjakan pekerjaan domestik yang tidak proporsional, seperti pekerjaan rumah tangga dan mengurus anak. Perempuan lebih terlihat miskin dari pada laki-laki, terutama dalam usia tua. Laki-laki mengambil porsi yang berlebih dalam kekuasaan politik, misalnya menjadi anggota parlemen. Perempuan memiliki pengalaman kekerasan dari laki-laki, seperti kekerasan dalam rumah tangga dan kekerasan seksual. Laki-laki terlihat memiliki pengaruh untuk membentuk kultur dan standar moral, misalnya sebagai editor koran dan pemuka agama. Tentu saja ada perkecualian individual dari kalimatkalimat tersebut, jika yang dimaksudkan adalah rata-rata peristiwa ketidakadilan gender, bukan apa yang dialami setiap lakilaki atau perempuan. Pola ketidakadilan gender tersebut berulang terus-menerus di dalam struktur sosial.
Terdapat beragam difinisi patriarki. Beberapa difinisi awal cenderung memfokuskan diri kepada peran laki-laki dewasa sebagai kepala rumah tangga (lihat kinship, family and marriage), meliputi fokus kepada generasi dan satu lembaga sosial yang spesifik. Definisi yang paling akhir saat ini tampak lebih leluasa, di mana lembaga-lembaga sosial dipandang berkontribusi dalam membentuk patriarki, dan keluarga menjadi salah satunya.

Konsep patriarki mengungkap adanya keterhubungan beragam aspek yang berbeda dalam ketidakadilan gender. Ada sebab yang saling berkaitan antara ketidakadilan gender dalam representasi politik dihubungkan dengan ketidakadilan dalam tempat kerja. Ketika ketidakadilan gender dalam kekuasaan politik menurun, jika perempuan meningkatkan representasinya di parlemen dan kabinet, muncul kecendrungan meningkatnya jumlah peraturan yang mendukung perempuan dalam pekerjaan, yang oleh karenanya mampu mempersempit jurang pemberian upah secara gender. Aspek yang lain, dimensi atau ranah patriarki dihubungkan. Keterhubungan ini berarti menjadi bukti adanya sistem ketidakadilan gender, bukan semata sekumpulan keterpisahan dan peristiwa-peristiwa yang tidak berkait satu dengan yang lain.

Pernyataan yang menunjuk adanya sistem sosial di dalam konsep patriarki menjadi penting bagi analisis Sosiologis mengenai ketidakadilan gender yang kemudian dapat melahirkan penjelasan yang lebih mendalam dan kuat terhadap 
aspek-aspek yang beragam dalam hubungan gender. Hal itu memungkinkan untuk membangun hubungan antara tingkat analisis yang beragam, struktur sosial dengan fenomena pada tingkat individual. Contohnya, perempuan membuat keputusan, namun tidak pada situasi saat pengambilan keputusan itu dilakukan: perempuan "memilih" pekerjaan paruh waktu dengan bayaran yang rendah karena hanya itulah pekerjaan yang cocok dengan waktu sekolah anak yang membuat pengasuhan anak semakin tidak berkualitas. Penjelasan mengenai "pilihan" perempuan tersebut akan semakin menguat jika dimasukkan unsur institusi sosial dan struktur sosial dalam analisis.

Beragam bentuk patriarki waktu dan tempat berbeda. Salah satu dimensi ragam tersebut mencakup patriarki domestic. Pada umumnya, perempuan cenderung tersisih dari pekerjaan-pekerjaan dengan upah tinggi karena jenis pekerjaan yang dapat diambil perempuan sudah ditentukan oleh laki-laki. (Bhasin, 1996:6) Dimensi ini bervariasi bergantung seberapa jauh perempuan dikendalikan dalam ruang domestik dan sejauh mana pula perempuan hadir dalam lembaga-lembaga publik, seperti pekerjaan, universitas dan parlemen. Dimensi kedua adalah tingkat ketidakadilan gender, contohnya seberapa besar jurang pemberian upah secara gender. Modernitas menjadi saksi bagi kecendrungan adanya transformasi bentuk patriarki dari bentuk domestik ke publik. Transformasi ini hanya sebagian berhubungan dengan perubahan dalam tingkat ketidakadilan, yang karenanya, dibutuhkan analisis yang terpisah terhaap dimensi tersebut. Arah modernisasi patriarki tidaklah seragam atau universal, melainkan sangat bergantung kepada arah modernisasi itu sendiri di mana perubahan-perubahan awal dan sejumlah hubungan-hubungan sosial yang lain memengaruhi arah perubahan tersebut.

Konsep patriarki terkadang mengundang kontroversi. Hal itu sering terjadi karena munculnya kesalahpahaman. Terutama, konsep patriarki sering diasumsikan bahwa analisis yang menggunakan konsep patriarki mestilah universalis dan esensialis, menurunkan perbedaan sosial antara laki-laki dengan perempuan pada sisi perbedaan biologis semata, dan mengabaikan perbedaan pola hubungan gender pada waktu dan tempat yang berbeda. Misalnya saja konsep kebebasan dan kemandirian bagi perempuan yang diproklamirkan oleh Islam sering disalahpahami. Kebebasan itu seringkali diidentikkan dengan kebebasan bergaul dengan lawan jenis dan eksploitasi tubuh untuk kepentingan seksual. Aikbatnya banyak muncul di permukaan adalah perempuanperempuan yang mempertontonkan keindahan tubuhnya untuk kepentingan komersial dan menjadi objek kapitalisme. (Mulia, 2014a:45).

Sebagai konsekuensinya, terdapat perkembangan istilah dalam patriarki untuk menangkap konsep sistem sosial ketidaksetaraan gender. Hal itu termasuk, misalnya, istilah "rezim gender". Penggunaan istilah gender yang lebih dari penggunaan istilah patriarki telah menghapus 
keraguan mengenai karakter sosial dari sistem sosial, lebih dari sekedar dasar biologis sistem sosial itu sendiri. Selanjutnya, istilah "rezim" lebih halus konotasinya daripada sistem, yang menandai pentingnya interaksi sejumlah hubunganhubungan sosial lainnya seperti, kelas dan etnisitas, dalam membentuk hubungan-hubungan gender. Dalam praktiknya, kedua istilah tersebut saling bertukar secara efektif, memaknai hal yang sama, yaitu sistem sosial ketiaksetaraan hubungan-hubungan gender.

Penambahan konsep patriarki ke dalam perbendaharaan kata Sosiologi memfasilitasi analisis hubungan-hubungan gender pada tingkat struktur dan sistem sosial, berkembang melebihi konsepsi gender yang ditentukan oleh biologi atau psikologi.

\section{Budaya Patriarki}

Budaya patriarki merupakan budaya dimana laki-laki mempunyai kedudukan lebih tinggi dari perempuan. Dalam budaya ini, ada perbedaan yang jelas mengenai tugas dan peranan perempuan dan laki-laki dalam kehidupan bermasyarakat, khususnya dalam keluarga. Budaya patriarki secara turun temurun membentuk perbedaan perilaku, status dan otoritas antara laki-laki dan perempuan di masyarakat yang kemudian menjadi hirarki gender.

Laki-laki sebagai pemimpin atau kepala keluarga memiliki otoritas yang meliputi kontrol terhadap sumber daya ekonomi, dan suatu pembagian kerja secara seksual dalam keluarga. hal ini menyebabkan perempuan memiliki akses yang lebih sedikit di sektor publik dibandingkan laki-laki.

Patriarki adalah istilah yang dipakai untuk menggambarkan sistem sosial di mana kaum laki-laki sebagai suatu kelompok mengendalikan kekuasaan atas kaum perempuan.

Islam bukan agama patriarki. Semua manusia adalah setara dan berasal dari sumber yang satu yaitu Allah swt, yang membedakan di antara manusia hanyalah prestasi dan kualitas takwa. Sebagaimana yang tercantum dalam Alquran surat alDzariyat 51: 56 yang artinya: Dan aku tidak menciptakan jin dan manusia melainkan supaya mereka mengabdi kepada-Ku. (Mulia, 2014b: 32).

Islam tidak mengajarkan bahwa kedudukan perempuan berada di bawah seorang laki-laki. Islam mengajarkan bahwa seorang perempuan ketika menikah maka tanggung jawab atas dirinya berada di diri laki-laki yang menjadi suaminya. Islam memberikan penghormatan yang besar terhadap perempuan, karena sebaik-baiknya laki-laki muslim adalah yang berbuat baik kepada istrinya. Islam memberikan kehormatan yang tinggi bagi para muslimah. Tidak ada kewajiban bagi mereka untuk mencari nafkah. Bukannya menggambarkan perempuan sebagai orang yang lemah dan tukang membebani laki-laki, tapi ini adalah penghormatan Islam kepada perempuan sehubungan dengan tugas mereka yang amat vital di dalam rumah keluarganya.

Islam memberikan kewajiban dan hak yang sama bagi laki-laki maupun perempuan, namun laki-laki 
diberikan satu tingkat lebih tinggi dibanding perempuan bukan untuk merendahkan tapi dalam sebuah rumah tangga laki-laki menjadi imam yang memiliki tanggung jawab serta tugas yang tidak mudah dalam menjaga istri dan anak-anaknya kelak.

\section{Budaya Patriarki Picu Kekerasan Terhadap Perempuan}

Kriminalitas seakan tak mau hengkang di negeri ini. Bagaimana tidak, persoalan ekonomi, sosial maupun budaya di masyarakat telah mendorong adanya kejahatan, baik itu kejahatan pencurian, penganiayaan, tindak asusila, pemerkosaan hingga kasus pembunuhan. Dari tindak kriminal yang ada, tak sedikit perempuan menjadi korban kekerasan atas aksi kejahatan, khususnya pemerkosaan dan tindak asusila. Budaya patriarki terus membelenggu, mengakibatkan laki-laki memandang rendah perempuan dan berbuat semenamena.

Misalnya saja kasus Priya Puspita Restanti (16) pada tahun 2013 silam, salah satu siswi SMK di Sleman yang telah menyita perhatian publik. Aksi kebiadaban yang dilakukan oleh ayah dan anak, juga keterlibatan oknum aparat kepolisian mencederai moral bangsa. Tindakan pemerkosaan dan pembunuhan dilakukan hanya untuk mencari kesenangan sesaat, dinilai melecehkan harkat dan martabat perempuan. Belum luput dari itu, lagi, kasus serupa (asusila) dilakukan oleh seorang nelayan menyetubuhi anak tirinya dari umur 12 tahun. Rentannya posisi perempuan sebagai dalang citra buruk, menjadi corong menguatnya aksi kriminalitas.

Perempuan sering menjadi ancaman dan sasaran dalam dunia kriminal. Terlebih dengan tabiat hawa nafsu laki-laki yang lebih besar dibanding perempuan, memicu untuk berbuat keji. Kemolekan perempuan telah meracuni pikiran dan niat yang buruk. Inilah bentuk keroposnya akhlak. Ada kalanya keimanan seseorang turun dan naik. Inilah yang harusnya menjadi tantangan laki-laki untuk mengendalikan syahwat, tentunya juga didukung oleh lingkungan perempuan yang memiliki akhlak yang baik pula, tidak mengumbar keindahan tubuh.

Refleksi akan lahirnya Hari

Kartini belum mampu menjadi cahaya dalam memperjuangkan emansipasi perempuan. Hari Kartini hanya dianggap isapan formalitas semata, bukan menjadi wajah refleksi untuk memperjuangkan hak yang sama. Terbukti dengan masih bergulirnya tindakan yang menyudutkan perempuan, yakni perlakuan buruk terhadapnya. Hal ini sudah membudaya di masyarakat yang harus dituntaskan, mengingat setiap manusia memiliki hak yang sama serta wajib menghormati atas kepribadian. Dalam Islam pun, perempuan dimuliakan. Tidak ada sekat di antara laki-laki, terkecuali jika mereka melakukan perbuatan keji. Hal ini mengindikasikan bahwa pola dan budaya masyarakat yang patut dibenahi, bukan karena perempuannya.

Budaya patriarki semacam ini, haruslah menjadi cerminan untuk terus memperjuangkan hak perempuan. Menghilangkan sebuah budaya tidaklah mudah, akan tetapi 
untuk menguranginya masih bisa menjadi harapan. Mensubtitusikan budaya yang lebih baik, mencitrakan perempuan sebagai sosok yang mulia, serta memperbaiki akhlak pribadi manusia bisa menjadi langkah kecil yang nyata untuk menumpas paradigma patriarki. Bila hal ini dilakukan, maka tingkat kriminalitas dengan korban perempuan akan ikut menurun juga.

\section{Dampak Patriarki Terhadap Konflik Yang Terjadi Di Indonesia}

Menurut Bhasin menjelaskan bahwa kata patriarki secara harafiah berarti kekuasaan bapak atau "patriakh (patriarch)". Pada awalnya patriarki digunakan untuk menyebut suatu jenis "keluarga yang dikuasai oleh kaum laki-laki”, yaitu rumah tangga besar patriarch yang dikuasai oleh laki-laki (Bhasin, 1996, p.1). Secara detail, patriarki merujuk pada sebuah bentuk organisasi rumah tangga dimana laki-laki mendominasi anggota keluarga yang lain dan mengontrol produksi ekonomi rumah tangga. Patriarki dipandang sebagai ideologi bagaimana laki-laki mendominasi. Masyarakat yang patriarkis adalah masyarakat yang dimana laki-laki memiliki kekuatan dan kontrol. Perempuan biasanya dieksploitasi, dirugikan dan mempunyai status yang lebih rendah.

Kultur patriarki mempengaruhi pola pikir masyarakat. Perbedaan gender telah melahirkan berbagai ketidakadilan, baik bagi kaum lakilaki dan terutama terhadap kaum perempuan. Ketidakadilan gender termanifestasikan dalam pelbagai bentuk ketidakadilan yaitu marginalisasi atau proses pemiskinan ekonomi, subordinasi anggapan tidak penting dalam keputusan politik, pembentukan stereotipe atau melalui pelabelan negatif, kekerasan, beban kerja yang panjang dan lebih banyak serta sosialisasi ideologi peran gender (Fakih, 1999:12-13). Sementara itu peran-peran sub ordinasi paling umum diperankan oleh perempuan dalam hubungan kekuasaan: perempuan berperan sebagai korektor (fixer), ia ingin hubungan itu stabil, harmonis dan menyenangkan; perempuan sebagai penyenang (pleaser), ia mencoba memenuhi harapan laki-laki; perempuan sebagai suhada (martyr): ia ingin pasangannya hidup senang sekalipun mengorbankan dirinya. Ketidakadilan gender yang ada dalam suatu rumah tangga akan menghasilkan konflik diantara suami istri yang jika dibiarkan terus berlanjut akan mengakibatkan perceraian. Hubungan perkawinan antar suami dan istri merupakan ikatan sentral persatuan keluarga di dalam masyarakat, apabila ikatan ini pecah, keluarga juga akan pecah (Ihromi, 1999:167).

Dalam kehidupan rumah tangga, laki-laki ditempatkan secara budaya sebagai kepala rumah tangga sedangkan istri sebagai ibu rumah tangga dimana posisinya selalu berada di bawah dominasi laki-laki. Perempuan dipandang lebih utama untuk berkiprah di sektor domestik, membersihkan rumah, memasak, mencuci, dan mengasuh anak. Jika ia bekerja di sektor publik, disamping harus memilih pekerjaan yang sesuai dengan kodratnya, dia tetap sebagai pembantu suami dalam memenuhi kebutuhan nafkah keluarga. 
Konflik di dalam masyarakat Indonesia dapat diawali dari konflik rumah tangga, hal ini terjadi karena rumah tangga merupakan komunitas terkecil yang memiliki pemahaman patriarki. Secara keseluruhan (kecuali Minangkabau), masyarakat Indonesia menganut patriarki sehingga pemikiran laki-laki lebih dominan dalam masyarakat pun semakin kuat.

Selain itu, sebagian besar konflik yang terjadi dikarenakan maskulinitas kebijakan yang diambil oleh pemerintah. Hanya sedikit yang mempertimbangkan kefemininitasan. Masyarakat Indonesia secara kultural memang sangat kental dengan adat patriarki. Hampir semua konflik yang terjadi karena adanya kebijakan penyelesaian dengan kekerasan. Bahkan, ketika Presiden Indonesia perempuan yakni Megawati Soekarnoputri pun menggunakan kebijakan Daerah Operasi Militer (DOM) bagi Gerakan Aceh Merdeka (GAM) yang menggunakan kekuatan militer yang sangat membuat traumatis bagi masyarakat Aceh.

\section{PENUTUP}

Budaya patriarki adalah di mana laki-laki menjadi kepala keluarga sekaligus dia pencari nafkah untuk keluarganya, dan di lingkungan keluarga isteri hanya sebatas bekerja di domestik di rumah tangga saja, walaupun sekarang perempuan mulai memperjuangkan hak-haknya sebagai perempuan. Hal ini sejalan dengan agama Islam, bahwa perempuan itu sangat di muliakan tanpa ada sekat di antara mereka. Sayangnya, nilai-nilai Islam yang begitu ideal dan luhur, ketika

turun ke bumi dan berinteraksi dalam kehidupan umat manusia, disengaja atau tidak, di sana sini telah terjadi distorsi.

Realitas sosial berkata lain, dengan adanya budaya patriarki ini membuat banyaknya tindak kekerasan terhadap perempuan. Perempuan sering menjadi ancaman dan sasaran dalam dunia kriminal. Terlebih dengan tabiat hawa nafsu laki-laki yang lebih besar dibanding perempuan, memicu untuk berbuat keji. Kemolekan perempuan telah meracuni pikiran dan niat yang buruk. Inilah bentuk keroposnya akhlak, celah-celah keimanan goyah dan menjadi peluang untuk mengajak ke perbuatan tercelah. Memang, ada kalanya keimanan seseorang turun dan naik. Inilah yang harusnya menjadi tantangan laki-laki untuk mengendalikan syahwat, tentunya juga didukung oleh lingkungan perempuan yang memiliki akhlak yang baik pula, tidak mengumbar keindahan tubuh.

\section{Ucapan Terima Kasih}

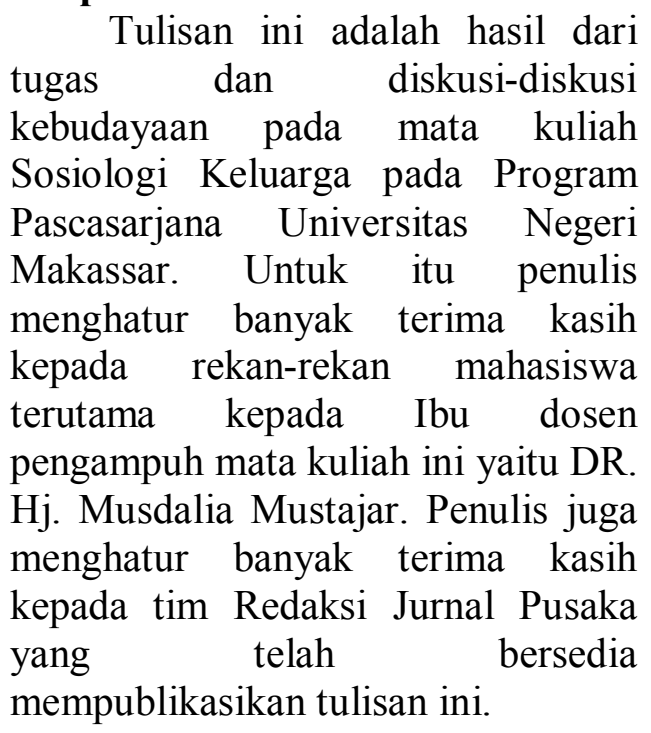




\section{DAFTAR PUSTAKA}

Berry. 1992. Psikology at Work. England: Oxford.

Bhasin, Kamla. 1996. Mengugat Patriarki, Pengantar Tentang Persoalan Dominasi Terhadap Kaum Perempuan (Terjemahan). Yogyakarta: Yayasan Bentang Budaya.

Fakih, Mansur. 1999. Analisis Gender \& Transformasi Sosial. Yogyakarta: Pustaka Belajar.

Goode, W.J. 2007.Sosiologi Keluarga. Jakarta: Bumi Aksara.

Ihromi. 1999. Bunga Rampai Sosiologi Keluarga. Jakarta: Yayasan Obor Indonesia.

Manurung, Ria. 2002. Kekerasan Terhadap Perempuan pada Masyarakat Multi Etnik. Yogyakarta: Pusat Studi Kependidikan dan Kebijakan UGM Ford Foundation.

Mulia, Musda. 2014. Indahnya Islam: Menyuarakan Kesetaraan \& Keadilan Gender. Yogyakarta: Nauvan Pustaka.

. 2014. Kemuliaan Perempuan dalam Islam. Jakarta: Megawati Institute.

Pinem, Saroha. 2009. Kesehatan Reproduksi dan Kontrasepsi. Jakarta: Trans Media.

Sastryani. 2007. Glosarium, Seks, dan Gender. Yogyakarta: Carasuati Books.
Spradley. 2007. Gender \& Pembangunan. Yogyakarta: Pustaka Belajar.

Walkins, Alice Susantro (dkk). 2007. Feminisme Untuk Pemula. Yogyakarta: Resist Book.

www.jurnalperempuan.org. diakses pada tanggal 28 Agustus 2017. 